\title{
Earthmoving Productivity in Urban Bridge Construction
}

\author{
Seonghoon Kim ${ }^{1, *}$, Yong Bai ${ }^{2}$ \\ ${ }^{1}$ Department of Civil Engineering and Construction Management, Georgia Southern University, USA \\ ${ }^{2}$ Department of Construction Management and Engineering, North Dakota State University, USA
}

Copyright $(\mathcal{C} 2015$ by authors, all rights reserved. Authors agree that this article remains permanently open access under the terms of the Creative Commons Attribution License 4.0 International License

\begin{abstract}
Earthmoving operations in urban bridge reconstruction projects are analyzed to identify significant factors that impact relatively low productivity. The research project was conducted in the urban interchange reconstruction of Interstate Highway 235 (I-235) in Des Moines, Iowa. By using observational studies and a statistical analysis method, the factors were identified, including match factor, number of passes, and loading cycle time per bucket. Number of truck, match factor, travel time, and hauling distance were identified as the unique factors for the off-site earthmoving project, while the start time and travel time were significant factors for the on-site project. This research also identified significant factors for the truck bunching and showed that the match factor from the urban earthmoving project does not linearly correlate with the productivity of each truck. Reducing the hauling distance for urban earthmoving projects was the principal method for improving productivity.
\end{abstract}

Keywords Earthmoving, Bridge, Highway, Productivity, Schedule, Iowa

\section{Introduction}

Earthmoving productivity has long been a major research subject in the area of construction engineering and management for the following reasons: (1) Earthmoving is included in most construction projects, such as highways, buildings, dams, harbors, airports, sewage and drainage systems, and industrial plants; (2) Earthmoving requires intensive equipment operations; (3) Estimating the earthmoving productivity not only determines the efficiency of operation but also identifies the significant factors that impact productivity. Proper planning and scheduling minimize waiting time and other delays, making the earthmoving process more productive, and decreasing the risk of cost overrun [1].

The efficiency of earthmoving operations varies widely, depending on properties of earth such as rugged earth, moisture content, and swelling and shrinkage factors. A computer program [2] was used to determine the coefficients in order to calculate the haul unit performance in an efficient, accurate, and convenient manner. Farid and Koning [3] proposed that maximum earthmoving productivity will be determined by the productivity of loading facilities regardless of the size, number, and speed of the hauling units. Christian and Xie [1] categorized the factors of earthmoving operations into machine selection, production, and cost based on a survey of industry data, as well as the opinions of experts. Smith [4] identified the factors that influence earthmoving operations by using linear regression techniques. Such factors include bucket capacity, match factor, and the total number of trucks being used. Simulation methods were utilized to identify optimized earthmoving operations for minimizing the total project cost, and the overall project duration, and the equipment idle time [5-7]. Global positioning system (GPS) equipment became methods to improve progress control and productivity for earthmoving operations [8-10]

\subsection{Urban Highway Earthmoving Productivity on I-235 in Des Moines}

The purpose of the reconstruction of I-235 was to widen and replace about 80 overpass bridges, install noise barriers and retaining walls, and reconstruct about 20 interchanges, main line pavements, and utility works. This project began in 2002 and was completed in 2007. The total cost of the project was expected to be $\$ 429$ million [11]. The earthmoving involved in this project constituted 20 percent of the total project cost.

The average earthmoving productivity of the thirteen I-235 reconstruction projects, located in the urban areas, was lower than the average rate of the seventeen rural highway projects based on the data provided by the Iowa Department of Transportation (Iowa DOT). Table 1 shows the difference between the two project groups. The daily average productivity was $3,222 \mathrm{yd}^{3}$ per day for seventeen rural projects. The average for the thirteen I-235 projects was $1,367 \mathrm{yd}^{3}$ per day, or approximately 40 percent of the rural earthmoving productivity. This comparison was based on the projects with volumes of less than 200,000 $\mathrm{yd}^{3}$ of earthmoving quantity per project and normal type of earth materials, such as loam, silt, gumbo, peat, clay, soft shale, 
sand, and gravel. Because of low productivity in the urban interchange projects, bidding prices ranged from 2 to 3 times higher than those of rural projects.

Table 1. Earthmoving Productivity for I-235 Reconstruction

\begin{tabular}{|c|c|c|c|c|}
\hline $\begin{array}{c}\text { Project } \\
\text { Type } \\
(1)\end{array}$ & $\begin{array}{c}\text { No. of } \\
\text { Projects } \\
(2)\end{array}$ & $\begin{array}{c}\text { Quantity } \\
\left(\mathrm{yd}^{3}\right) \\
(3)\end{array}$ & $\begin{array}{c}\text { Working } \\
\text { Period (days) } \\
(4)\end{array}$ & $\begin{array}{c}\text { Productivity } \\
\left(\mathrm{yd}^{3} / \text { day }\right) \\
(5)\end{array}$ \\
\hline $\begin{array}{c}\text { Rural } \\
\text { Projects }\end{array}$ & 17 & $1,392,000$ & 432 & 3,222 \\
\hline $\begin{array}{c}\text { I-235 } \\
\text { Urban } \\
\text { Projects }\end{array}$ & 13 & 832,548 & 609 & 1,367 \\
\hline
\end{tabular}

Note: Quantities for the I-235 project were based on the as-built quantity until June 2004

Iowa Department of Transportation (Iowa DOT) focused on two main factors for successful completion of the entire I-235 corridor, which were to (1) decrease adverse effects due to delays from previous projects and (2) encourage the projects to collaborate worksites. The reconstruction projects are performed in the urban area of Des Moines where features contribute to lower production rates than those of rural areas. To succeed in the urban projects, the possibility of improving productivity for each project becomes a key issue. A comprehensive literature review showed that there were a few techniques that could be used to improve productivity for urban highway projects. O'Connor and El-Diraby [12] provided methods for optimizing urban bridge construction. Lee et al. [13] reported the most economical traffic closure scenario for urban highway paving projects so that transportation agencies and contractors achieved minimum construction costs and user road costs. However, there is a limited amount of literature on urban earthmoving productivity improvement, although there have been many research projects which focused on earthmoving productivity improvement. Thus, it is important to conduct research to identify factors that have a significant impact upon urban earthmoving productivity and to develop methods to improve the productivity.

\subsection{Research Objective and Scope}

The primary objective of this research was to identify factors that impact earthmoving productivity in urban interchange reconstruction projects. The required data were collected via construction documents, site observations, and interviews with earthmoving contractors and inspectors. Forty-five earthmoving operations in the I-235 reconstruction project were observed and recorded using the time-study method, then statistical analysis was conducted to determine the cause and effect factors. The data were gathered from two interchange reconstruction sites.

\subsection{Methodology}

An urban earthmoving operation is defined as construction in an area where there is an increased density of man-made structures in comparison to the surrounding areas. In this research, two projects were selected from I-235 urban interchange reconstruction projects, both of which began and ended in 2004. Four different types of earthmoving operations were randomly selected from these interchange reconstruction projects. Equipment fleet for those operations included trucks and an excavator.

The time-scaled data were collected during weekly site visits after literature review. A multiple regression modeling was used for data analyses to determine factors that impacts earthmoving productivity, or the response variable. A total of nine explanatory variables were gathered from job sites and these variables were used to estimate productivity for earthmoving operations. Explanatory variables in this research were the number of trucks, bucket capacity, start time, the number of passes, loading cycle time, truck spot time, truck travel time, truck dump time, and lastly, hauling distance. From this point forward, the nine collected data were used to determine the significant factors that impact the productivity. In addition, eight calculated variables were included in the analysis.

The number of loader was not included as an explanatory variable because the collected data were all single loader operations. Rolling resistance and grade resistance were not considered for calculating earthmoving productivity in this research, because this research assumed that most of the hauling roads were composed of asphalt paving and low gradient. Thus, total resistance, the sum of these two resistances could be considered to be the same for I-235 earthmoving projects according to the Caterpillar Performance Handbook [14].

\subsubsection{Match Factor and Estimating Productivity}

Under conventional theories, the capacity of each truck will determine overall output and output will linearly increase as more trucks are added until the loader production capacity is reached. This conventional theory has been used to estimate the productivity of truck-loader fleets for many years. The Match Factor (MF) is indicative of the suitability of the size of the truck fleet; it is used to determine the efficiency of the fleet. Mogan and Peterson [15] developed the match factor to estimate the appropriate number of trucks and number of loaders:

$$
\text { Match Factor }=\frac{\text { Number of Haulers } \times \text { Loader Cycle Time }}{\text { Number of Loaders } \times \text { Hauler CycleTime }}
$$

When the match factor equals 1 , the operation is referred to as the ideal condition for determining the number of machines and the cycle time of equipment. If $\mathrm{MF}<1$, the operation indicates that less than the ideal number of hauling units are employed. If $\mathrm{MF}>1$, it indicates that there are more haulers than the operation needs. Consequently, the overall efficiency will be no longer increased if $\mathrm{MF}>1$ [16].

In an earthmoving operation, three different productivity levels could be estimated based upon data gathered. These are maximum productivity, possible productivity, and actual productivity. Possible productivity depends on loader production and actual productivity depends on hauling unit 
production. The maximum productivity can be calculated using the following formula.

$$
\begin{aligned}
& \left.P_{\max }=\text { Load Cycle Rate (loads / } 10 \text { hours }\right) \times \\
& \times \text { Load Volume per Cycle }\left(\mathrm{m}^{3}\right)
\end{aligned}
$$

Possible productivity will be lower than maximum productivity when the number of available hauling units is insufficient to keep the loader busy.

$$
\begin{aligned}
& P_{\text {possible }}=P_{\max } \times M F \text { for } M F<1 \\
& P_{\text {possible }}=P_{\max } \text { for } M F \geq 1
\end{aligned}
$$

Actual productivity is determined by the following equation:

$$
\begin{aligned}
& P_{\text {actual }}=\text { Hauler Cycle Rate }(\text { cycles } / 10 \text { hours }) \times \\
& \times \text { Load Volume }\left(\mathrm{m}^{3}\right)
\end{aligned}
$$

With the calculations above, the bunch factor is determined by the following equation:

$$
\text { Bunch Factor }=\frac{P_{\text {actual }}}{P_{\text {possible }}}
$$

Bunching certainly occurs in a system of a loader and its correlating fleet of trucks. If a truck has a greater cycle time due to the loader's delay, this delay time affects either the queue or the fleet cycle time. Therefore, many contractors consider the bunch factor to be a valid measure of earthmoving productivity.

The truck possible productivity can reach 100 percent if the match factor is equal to or greater than 1 as illustrated in Figure 1. Unlike the possible productivity, the operation efficiency of 100 percent does not correspond to $M F=1$. The match factor for 100 percent operation efficiency is reached at 1.8 as the efficiency increases by adding more haulers. Even if the efficiency is at 100 percent, this efficiency level is not considered at its optimal level because the additional haulers increase the cost more than they increase profits [4]. The previous research [17] demonstrated that optimal cost fleets can have operational efficiency as low as 50 percent.

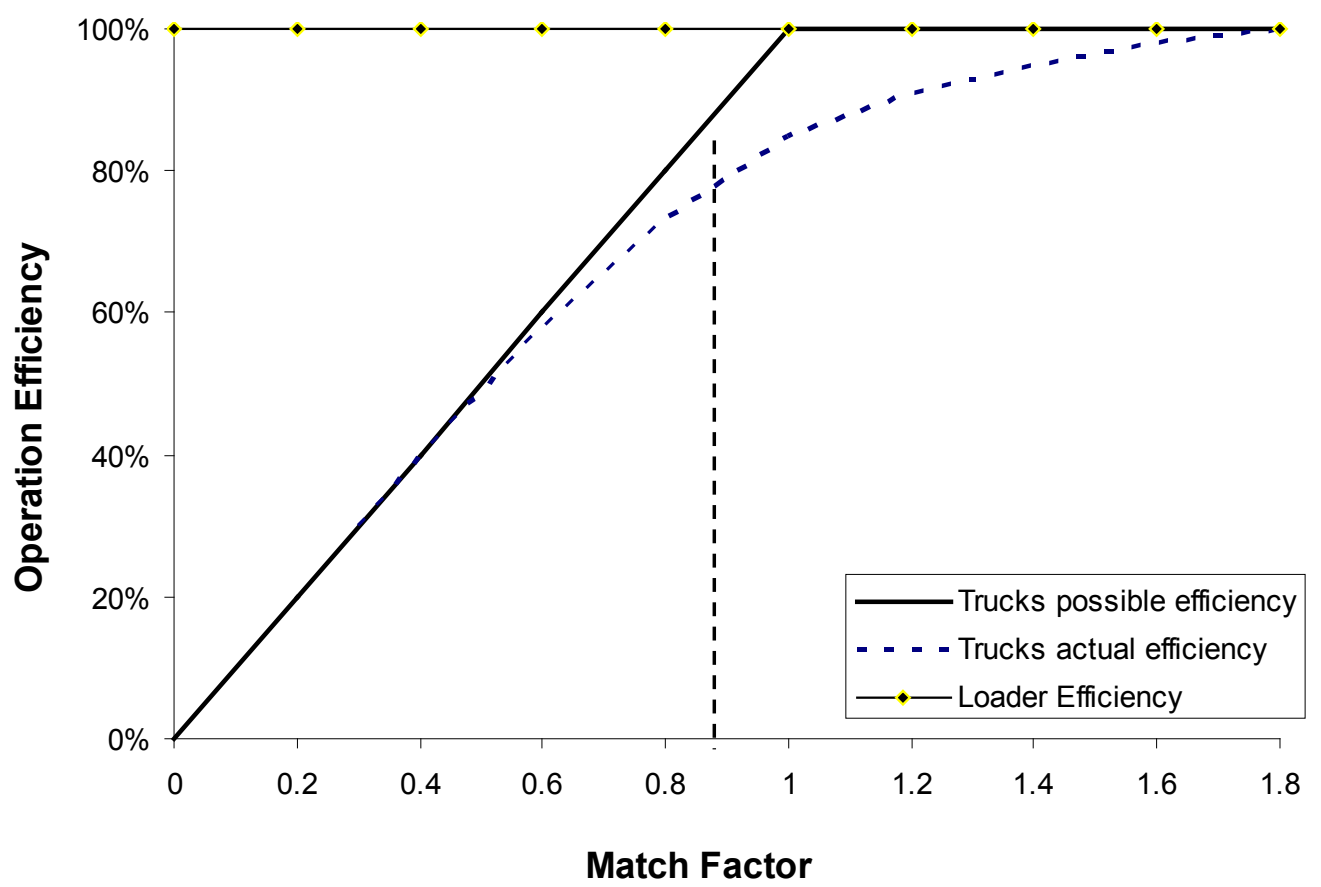

Figure 1. Match Factor vs. Operation Efficiency [4]

Table 2. Average of Raw Data Gathered from Job Sites

\begin{tabular}{|c|c|c|c|c|c|c|c|c|c|c|}
\hline $\begin{array}{c}\text { Project } \\
(1)\end{array}$ & $\begin{array}{c}\text { No. of } \\
\text { Data } \\
(2)\end{array}$ & $\begin{array}{c}\text { No. of } \\
\text { Truck } \\
(3)\end{array}$ & $\begin{array}{c}\text { B.C. }\left(\mathrm{m}^{3}\right) \\
(4)\end{array}$ & $\begin{array}{c}\text { Start Time }(\mathrm{Sec}) \\
(5)\end{array}$ & $\begin{array}{c}\text { No. of } \\
\text { Passes } \\
(6)\end{array}$ & $\begin{array}{c}\text { LCT } \\
(\mathrm{Sec}) \\
(7)\end{array}$ & $\begin{array}{c}\text { Spot } \\
\text { Time } \\
(\mathrm{Sec}) \\
(8)\end{array}$ & $\begin{array}{c}\text { T.T. } \\
(\mathrm{Min}) \\
(9)\end{array}$ & $\begin{array}{c}\text { Truck } \\
\text { D.T. } \\
(\mathrm{Sec}) \\
(10)\end{array}$ & $\begin{array}{c}\text { H.D. } \\
(\mathrm{mile}) \\
(11)\end{array}$ \\
\hline 1 & 8.0 & 4.0 & 2.5 & 29.6 & 5.5 & 290.1 & 57.1 & 41.3 & 70.3 & 20.7 \\
\hline 2 & 12.0 & 2.0 & 2.0 & 19.5 & 6.0 & 105.6 & 39.3 & 30.3 & 75.3 & 2.0 \\
\hline 3 & 16.0 & 2.0 & 2.2 & 27.2 & 4.6 & 131.1 & 17.4 & 2.6 & 44.8 & 0.3 \\
\hline 4 & 9.0 & 10.0 & 2.0 & 196.7 & 5.0 & 152.6 & 17.8 & 38.1 & 60.0 & 16.0 \\
\hline
\end{tabular}


Table 3. Average of Data Calculated

\begin{tabular}{|c|c|c|c|c|c|c|c|c|}
\hline $\begin{array}{c}\text { Project } \\
(1)\end{array}$ & $\begin{array}{c}\text { LCT per } \\
\text { Bucket } \\
(2)\end{array}$ & $\begin{array}{c}\text { Truck C.T. (Min) } \\
(3)\end{array}$ & $\begin{array}{c}\text { Match Factor (MF) } \\
(4)\end{array}$ & $\begin{array}{c}\text { Speed } \\
(\text { mile/hour }) \\
(5)\end{array}$ & $\begin{array}{c}\mathrm{P}_{\text {actual }} \\
\text { unit(m/day) } \\
(6)\end{array}$ & $\begin{array}{c}\mathrm{P}_{\text {actual }} \\
(7)\end{array}$ & $\begin{array}{c}\mathrm{P}_{\text {possible }} \\
(8)\end{array}$ & $\begin{array}{c}\text { Bunch Factor } \\
(9)\end{array}$ \\
\hline 1 & 54.1 & 47.8 & 0.4 & 26.2 & 61.9 & 222.9 & 415.9 & 0.6 \\
\hline 2 & 17.5 & 33.6 & 0.1 & 4.6 & 147.1 & 294.1 & 397.5 & 0.7 \\
\hline 3 & 28.9 & 6.3 & 0.7 & 2.5 & 499.6 & 999.2 & 1486.5 & 0.7 \\
\hline 4 & 30.7 & 45.3 & 0.6 & 21.3 & 89.4 & 896.5 & 1015.9 & 0.9 \\
\hline
\end{tabular}

\section{Data Collection}

A total of 45 earthmoving operations from four urban earthmoving projects were observed. Time studies were conducted using a stopwatch to collect the raw data. Additional information on site conditions, project sizes, and site features were obtained through site visits, interviews with inspectors and contractors, and through the inspection of documents from the Iowa Department of Transportation. For each individual truck, the hauling distance and travel time were measured. In addition, the truck bunching and deposit point, or dumping area, were also identified.

The averaged raw data are presented in Table 2. Project 1, 2, 3, and 4 represent earthmovings for Polk Boulebard to 42nd street, 42nd street, 14th street, and 42nd street Ramp B respectively (See Table 2). B.C. represents Bucket Capacity. Start time is the time between when the loader driver honks to inform the truck driver about the end of loading and the truck starts to travel. Number of passes refers to the number of load actions for one loading cycle time. Loading cycle time (LCT) is the period of time for the loader from the excavation pit to load the truck. Spot time is the time for the truck to pull near the loader once it reaches the site. Travel time (T.T.) is hauling time for the truck to go roundtrip from loading to dumping. Truck dump time (Truck D.T.) is the time between stopping at the deposit point and dumping material. Hauling distances (H.D.) were determined based on odometer readings from the loading spot to the deposit point.

The results of calculations on the overall level of productivity are shown in Table 3. Each variable in Table 3 is defined as follows: (2) Loading cycle time per bucket is the time period that loading cycle time is divided by the number of passes; (3) Truck cycle time is the sum of start time, spot time, loading cycle time, travel time, and truck dump time. (4) Match factor is calculated based on the equation (1); These three productivity figures and the bunch factor, based on 10 hours of working conditions, are used for a multiple regression model to determine the significant factors of urban earthmoving reconstruction.

\section{Regression Model and Analysis}

A multiple linear regression model was developed to predict the productivity per hauling unit for the urban earthmoving operation and to determine factors that made a significant impact upon that productivity. The productivity per hauling unit represented how effectively the earthmoving operation was executed in the field. Thus, the productivity per hauling unit was selected as the response variable against 11 explanatory variables, which were the number of truck, match factor, bucket capacity, start time, number of passes, loading cycle time (LCT), spot time, travel time, truck dump time, hauling distance, and loading cycle time per bucket. The cycle time was not selected as an explanatory variable, because the variable was composed of four variables included in the 11 explanatory variables. The regression model on the bunch factor was also developed to determine the factor that impacted the actual productivity.

In this research, data from the four earthmoving projects were analyzed, and then the data sets according to the range of productivity per hauling unit were divided into two categories: (1) productivity less than $350 \mathrm{~m}^{3} /$ day, and (2) productivity between $350 \mathrm{~m}^{3} /$ day and $750 \mathrm{~m}^{3} /$ day.

Table 4 shows the coefficients of determination as well as the number of observations for each data set. The range of the coefficients of determination is from 0.94 to 0.99 . For example, the coefficient of determination $\left(\mathrm{R}^{2}\right)$ of 0.94 from the four earthmoving projects indicates that 94 percent of the variation in the explanatory variables can be explained by the regression model. The coefficients for each data set were close to 1 , meaning that the regression line was a valid explanation of the variations in this model.

Table 4. $\mathrm{R}^{2}$ and the Number of Observation for Each Data Set

\begin{tabular}{|c|c|c|c|c|}
\hline \multirow{2}{*}{$\begin{array}{c}\text { Data Set } \\
(1)\end{array}$} & \multicolumn{2}{|c|}{ Unit Production } & \multicolumn{2}{c|}{ Bunch Factor } \\
\cline { 2 - 5 } & $\begin{array}{c}\text { R Square } \\
(2)\end{array}$ & $\begin{array}{c}\text { Observations } \\
(3)\end{array}$ & $\begin{array}{c}\text { R Square } \\
(4)\end{array}$ & $\begin{array}{c}\text { Observations } \\
(5)\end{array}$ \\
\hline Earthmoving $(4 \mathrm{projects})$ & 0.94 & 45 & 0.97 & 45 \\
\hline Production $\left(0-350 \mathrm{~m}^{3} /\right.$ day $)$ & 0.95 & 29 & 0.98 & 29 \\
\hline Production $\left(350-750 \mathrm{~m}^{3} /\right.$ day $)$ & 0.99 & 16 & 0.98 & 16 \\
\hline
\end{tabular}


Table 5. Parameter Estimates on Productivity per Hauling Unit

\begin{tabular}{|c|c|c|c|c|c|c|}
\hline $\begin{array}{c}\text { Variables } \\
(1)\end{array}$ & $\begin{array}{c}\text { Coefficients } \\
(2)\end{array}$ & $\begin{array}{c}\text { Standard Error } \\
(3)\end{array}$ & $\begin{array}{c}\text { t-Statistic } \\
(4)\end{array}$ & $\begin{array}{c}\text { P-value } \\
(5)\end{array}$ & $\begin{array}{c}\text { Lower 95\% } \\
(6)\end{array}$ & $\begin{array}{c}\text { Upper 95\% } \\
(7)\end{array}$ \\
\hline Intercept & $\mathbf{6 7 1 . 4 0 0}$ & $\mathbf{9 0 3 . 6 0 0}$ & $\mathbf{0 . 7 4 3}$ & $\mathbf{0 . 4 6 3}$ & $\mathbf{- 1 1 6 6 . 9 8 7}$ & $\mathbf{2 5 0 9 . 7 8 7}$ \\
\hline No of Truck & -24.323 & 30.205 & -0.805 & 0.426 & -85.776 & 37.130 \\
\hline Match Factor & $\mathbf{4 7 7 . 5 2 9}$ & $\mathbf{1 8 6 . 2 0 5}$ & $\mathbf{2 . 5 6 5}$ & $\mathbf{0 . 0 1 5}$ & $\mathbf{9 8 . 6 9 2}$ & $\mathbf{8 5 6 . 3 6 5}$ \\
\hline Bucket Capacity $\left(\mathrm{m}^{3}\right)$ & 37.693 & 382.767 & 0.098 & 0.922 & -741.052 & 816.438 \\
\hline Start & -0.147 & 0.242 & -0.607 & 0.548 & -0.639 & 0.345 \\
\hline No. of Passes & $\mathbf{- 8 9 . 8 9 5}$ & $\mathbf{3 1 . 1 0 6}$ & $\mathbf{- 2 . 8 9 0}$ & $\mathbf{0 . 0 0 7}$ & $\mathbf{- 1 5 3 . 1 8 1}$ & $\mathbf{- 2 6 . 6 1 0}$ \\
\hline Loading Cycle Time & 0.856 & 0.636 & 1.346 & 0.188 & -0.438 & 2.149 \\
\hline Spot & 0.137 & 1.604 & 0.085 & 0.932 & -3.126 & 3.400 \\
\hline Travel Time (Min) & -0.866 & 0.726 & -1.193 & 0.241 & -2.344 & 0.611 \\
\hline Truck D.T(Sec) & 0.139 & 0.913 & 0.152 & 0.880 & -1.718 & 1.996 \\
\hline Hauling Distance (mile) & -3.618 & 11.407 & -0.317 & 0.753 & -26.826 & 19.590 \\
\hline LCT per Bucket & $\mathbf{- 8 . 3 0 7}$ & $\mathbf{3 . 0 1 7}$ & $\mathbf{- 2 . 7 5 3}$ & $\mathbf{0 . 0 1 0}$ & $\mathbf{- 1 4 . 4 4 5}$ & $\mathbf{- 2 . 1 6 9}$ \\
\hline
\end{tabular}

The t-statistic is the ratio of the coefficient to its standard error to test the significance of the regression model. In the Table 5, the t-statistic of the match factor is $t=477.529 / 186.205=2.565$ and the value is greater than the critical t-value at a level of significance of 5 percent, $\mathrm{t}_{(0.025 ; \mathrm{n}-\mathrm{p}-1)}=2.04$. Since the corresponding probability of 0.015 is less than the $\mathrm{P}$-value 0.05 , the null hypothesis $(\mathrm{H} 0)$, which is $\beta_{1}=0$, can be rejected. Accordingly, other two explanatory variables, No. of passes and LCT per bucket, were selected as significant factors at the 95 percent confidence level $(\alpha=0.05)$. The predicted productivity $\hat{y}_{i}$ can be estimated by the following mathematical formula based on the coefficients of three explanatory variables (bold text) in Table 5. The intercept in a multiple regression model is often labeled the constant and the mean for the response when all of the explanatory variables take on the value 0 .

$$
\hat{y}_{i}=671.400+477.529 x_{1 i}-89.895 x_{2 i}-8.307 x_{3 i}
$$

$$
\begin{aligned}
& x_{1 i}: \text { Match Factor } \\
& x_{2 i}: \text { No. of Passes } \\
& x_{3 i}: \text { Loading Cycle Time per Bucket }
\end{aligned}
$$

An ANOVA (Analysis of Variance) test determined whether the regression model for the four earthmoving projects was statistically significant. The $\mathrm{F}$ value of 47.4 revealed that the entire regression was significant because the test statistic $F$ value was greater than the critical $F$ value $\left(F_{\text {critical }}=F_{0.05 ; 11,33}=2.13\right.$ for a significance level of 0.05$)$. It means that at least one of 11 variables was not zero, indicating that we rejected the null hypothesis of $\mathrm{H}_{0}$ : $\beta_{1}=\beta_{2}$ $=\cdots=\beta_{11}=0$. Consequently, the urban earthmoving productivity and the explanatory variables in Table 6 were linearly correlated.
Table 6. ANOVA Table on Productivity for the Four Projects

\begin{tabular}{|c|c|c|c|c|c|}
\hline $\begin{array}{c}\text { Source } \\
(1)\end{array}$ & $\begin{array}{c}\text { Df } \\
(2)\end{array}$ & $\begin{array}{c}\text { SS } \\
(3)\end{array}$ & $\begin{array}{c}\text { MS } \\
(4)\end{array}$ & $\begin{array}{c}F \\
(5)\end{array}$ & $\begin{array}{c}F_{(0.05)} \\
(6)\end{array}$ \\
\hline Regression & 11 & 1726970.5 & 156997.3 & 47.4 & 2.13 \\
\hline Residual & 33 & 109314.3 & 3312.6 & & \\
\hline Total & 44 & 1836284.8 & & & \\
\hline
\end{tabular}

Table 7. Significant Factors on Earthmoving Productivity per Hauling Unit

\begin{tabular}{|c|c|c|c|}
\hline \multirow{2}{*}{$\begin{array}{c}\text { Variables } \\
(1)\end{array}$} & $\begin{array}{c}\text { Off-site } \\
\text { Earthmoving } \\
0-350\left(\mathrm{~m}^{3}\right) \\
(2)\end{array}$ & $\begin{array}{c}\text { Coefficients } \\
\text { En-site } \\
350-750 \\
\left(\mathrm{~m}^{3}\right) \\
(3)\end{array}$ & $\begin{array}{c}\text { Earthmoving } \\
(4 \text { projects }) \\
(4)\end{array}$ \\
\hline Intercept & 400.461 & 1523.759 & 671.400 \\
\hline No of Truck & -13.042 & & \\
\hline M.F. & 178.529 & & 477.529 \\
\hline $\begin{array}{c}\text { Bucket Capacity } \\
\left(\mathrm{m}^{3}\right)\end{array}$ & & -4.252 & \\
\hline Start & & & -89.895 \\
\hline $\begin{array}{c}\text { No. of Passes } \\
\text { Loading C.T. }\end{array}$ & & & \\
\hline Spot & & -201.386 & \\
\hline $\begin{array}{c}\text { Travel Time } \\
\text { (Min) }\end{array}$ & -1.380 & & \\
\hline Truck D.T. (Sec) & & & -8.307 \\
\hline H.D. (mile) & -3.248 & & \\
\hline LCT per Bucket & & & \\
\hline
\end{tabular}

This research garnered results similar to the previous research in terms of the significant factors for earthmoving productivity. The significant factors in the earthmoving operations determined from the previous research were the number of trucks, bucket capacity, match factor, truck travel time, and hauling distance [4]. In Table 7, significant factors for earthmoving productivity per hauling unit with 
the coefficients are presented. Number of truck, match factor, travel time, and hauling distance were identified as significant factors in the urban earthmoving project with productivity ranged from 0 to $350 \mathrm{~m}^{3}$. For the on-site project with productivity from 350 to $750 \mathrm{~m}^{3}$, start time and travel time are significant factors. Number of passes, match factor, and loading cycle time per bucket also proved significant for the four earthmoving projects. In this research, on-site project represents earthmoving operation performed in the job site. In addition, loading in off-site projects was carried out on the job site but dumping occurred outside.

Table 8. Significant Factors on Bunch Factor

\begin{tabular}{|c|c|c|c|}
\hline \multirow{2}{*}{$\begin{array}{c}\text { Variables } \\
(1)\end{array}$} & $\begin{array}{c}\text { Off-site } \\
\text { Earthmoving } \\
0-350\left(\mathrm{~m}^{3}\right) \\
(2)\end{array}$ & $\begin{array}{c}\text { Coefficients } \\
\begin{array}{c}\text { On-site } \\
350-750\left(\mathrm{~m}^{3}\right) \\
(3)\end{array}\end{array}$ & $\begin{array}{c}\text { Earthmoving } \\
(4 \text { projects }) \\
(4)\end{array}$ \\
\hline Intercept & 1.704 & & 5.297 \\
\hline No of Truck & 0.0469 & & -0.054 \\
\hline M.F. & & & \\
\hline B.C $\left(\mathrm{m}^{3}\right)$ & & & \\
\hline Start & & & -0.236 \\
\hline No. of Passes & -0.184 & & 0.002 \\
\hline Loading C.T & 0.0016 & & 0.002 \\
\hline Spot & 0.0022 & & \\
\hline $\begin{array}{c}\text { Travel Time } \\
\text { (Min) }\end{array}$ & & & \\
\hline Truck D.T (Sec) & & & -0.011 \\
\hline H.D (mile) & -0.0218 & & \\
\hline LCT per Bucket & -0.0067 & & \\
\hline
\end{tabular}

The difference between this research and previous studies was that the number of passes was a statistically significant factor. The number of passes was a negative factor that reduced the productivity as the number of passes increased. The regression model for the bunch factor was not defined in previous research [4]. During this research, explanatory variables correlated with the bunch factor were tested except for the productivity range from 350 to $750 \mathrm{~m}^{3}$. However, other regression models were not defined by the bunch factor (see Table 8).

Figure 2 illustrates the relationship between the overall efficiency of earthmoving operations and the match factor. The data for urban earthmoving productivity does not match the possible productivity, which increases the overall efficiency as the match factor increases until it reaches one. As previously described on the match factor, the productivity is the highest when the match factor is approximately 1.8 after truck bunching is taken into account. However, the match factors for the 14th St. earthmoving project, the best practices observed within those data, were only 0.7 in the average, indicating that the project needs more hauling resources based on the previous research. In practice, the hauling units were employed in enough numbers since there was continuous queuing by trucks due to the space restriction. Space limitations, one of the features in urban interchange reconstruction, should be considered for match factor because the restricted space often limits room for additional hauling equipment. For example, the average match factor in the 14th Street project was 0.7, even if only a little bunching was found and was relatively well-executed in small enough space where no more equipment could be employed.

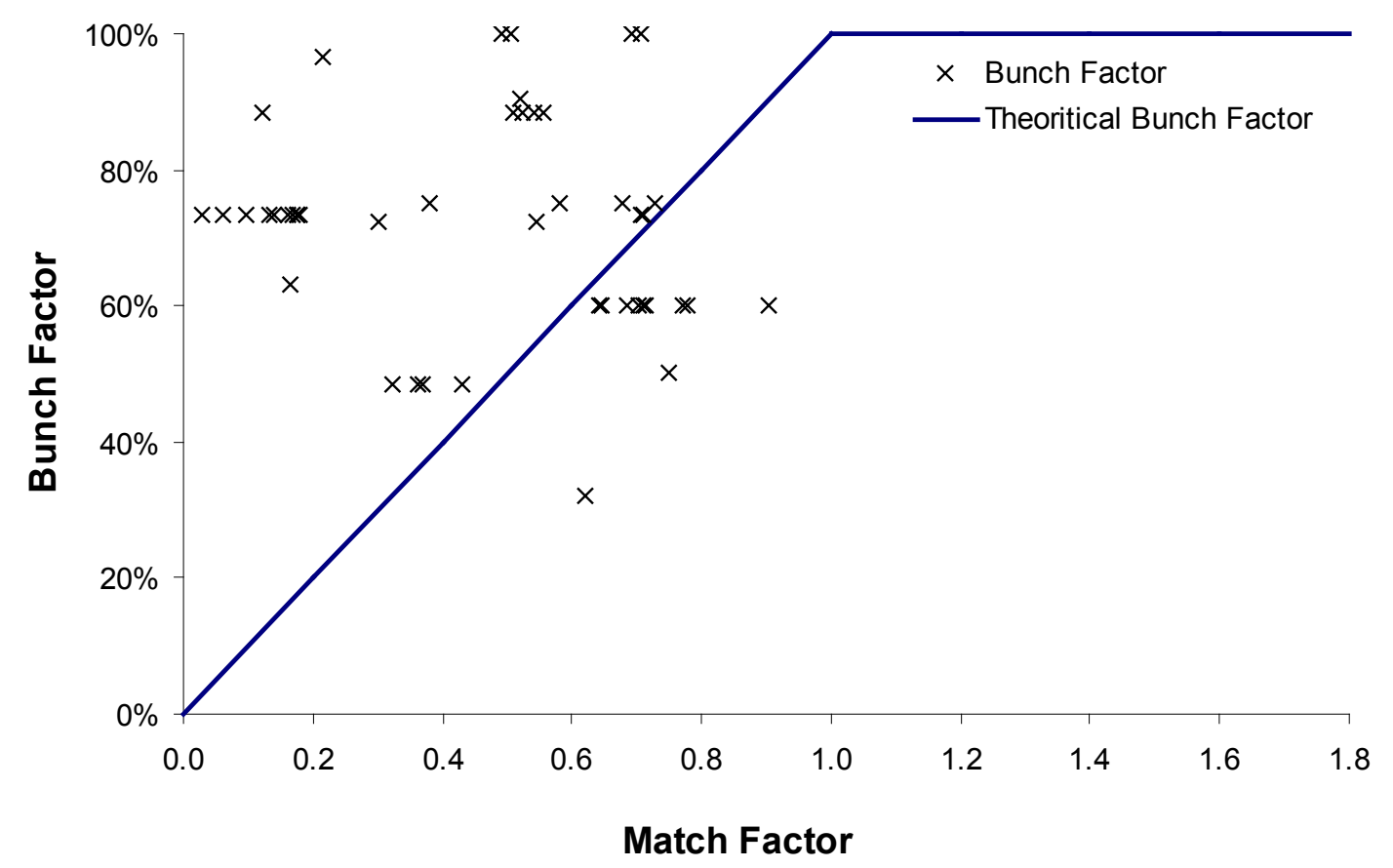

Figure 2. Match Factor vs. Bunch Factor 


\section{Conclusion and Recommendations}

Earthmoving in urban interchange construction faces many potential barriers that can increase the project duration and costs. Identifying significant factors involved in productivity and site observations coupled with time studies provided useful information on the causes of low productivity in urban interchange reconstruction projects.

Match factor, loading cycle time per bucket, and number of passes were identified as significant factors for urban earthmoving. Number of truck, match factor, travel time, and hauling distance were identified as the unique factors for off-site earthmoving projects, while the start time and travel time were significant factors for on-site projects.

The bunch factor and the match factor were defined differently in the urban earthmoving project. The bunch factor was defined by regression modeling, whereas in the previous research, the bunch factor could not defined by the multiple regression model. The number of trucks, number of passes, loading cycle time, spot, hauling distance, and loading cycle time per bucket were all significant for the bunch factors.

Hauling distance is a negative factor for off-site earthmoving productivity, indicating two important concepts: (1) reducing the hauling distance is the key point in increasing earthmoving productivity, and (2) in multiple urban highway projects, as in the I-235 project in Des Moines, a productivity study with the proper pre-planning is essential for balancing earth in overall job sites. Consequently, the pre-planning phase is an appropriate time to consider these two concepts. In other words, establishing an adequate stockpile or deposit point on-site is an important method for improving earthmoving productivity in urban interchange reconstruction.

Match factor is not necessary when truck access is limited by utility work, small excavation quantity, and restricted space. It is a possible assumption that the match factor can be better used in the linear earthmoving and mass excavation site, such as harbor construction, new main-line highway projects, and airport construction. When applying the match factor for productivity analysis of urban interchange reconstruction, the job site area should be spatial enough for the earthmoving to be executed in a continuous manner. In several projects in the I-235 urban interchange reconstruction, the researchers found that maintaining a match factor of 1 through the employment of more trucks was ultimately not worthwhile.

Additional significant factors for urban earthmoving operations might have been identified if the scope of data was extended. Although several significant variables were not identified in this research, the optimal amount of equipment on the job site, the contractor management skill level, the specific variables of the area itself in terms of restricted deposit points, the work space, access time to hauling route, and the traffic open scenario could be considered. These variables could be additional significant factors to earthmoving productivity for urban interchange reconstruction.

\section{Acknowledgements}

The authors would like to thank the Iowa Department of Transportation and contractors involved in the I-235 reconstruction project for supporting this research by providing financial resources, project notes, documents, and access to the construction sites.

\section{REFERENCES}

[1] Christian, J. and T.X. Xie. More realistic intelligence in earthmoving estimates. 1994. University Park, PA, USA: Computational Mechanics Publ, Southampton, Engl.

[2] Hicks, J.C., Haul-unit performance. Journal of Construction Engineering and Management, 1993. 119(3): p. 646-653.

[3] Farid, F. and T.L. Koning, Simulation verifies queuing program for selecting loader-truck fleets. Journal of Construction Engineering and Management, 1994. 120(2): p. 386-404.

[4] Smith, S.D., Earthmoving productivity estimation using linear regression techniques. Journal of Construction Engineering and Management, 1999. 125(3): p. 133-141.

[5] Tromposch, E. and J.H. Armitage, Design-construction of Fox Hollow pedestrian bridge. PCI Journal, 1997. 42(6): p. 50-59.

[6] Marzouk, M. and O. Moselhi, Object-oriented Simulation Model for Earthmoving Operations. Journal of Construction Engineering and Management, 2003. 129(2): p. 173-181.

[7] Montaser, A., et al., Estimating productivity of earthmoving operations using spatial technologies. CANADIAN JOURNAL OF CIVIL ENGINEERING, 2012. 39 9: p. p1072-p1082.

[8] Christoffersen, J., et al., Innovative cable-stayed bridge. Concrete (London), 1998. 32(7): p. 32-34.

[9] Navon, R. and Y. Shpatnitsky, Field Experiments in Automated Monitoring of Road Construction. Journal of Construction Engineering and Management, 2005. 131(4): p. 487-493.

[10] Han, S., Productivity Analysis Comparison of Different Types of Earthmoving Operations by Means of Various Productivity Measurements. Journal of Asian Architecture and Building Engineering, 2010. 9(1): p. 185-192.

[11] Swanson, J.A. and J. Windau, Rapid rehabilitation. Modern Steel Construction, 2004. 44(6): p. 53-54.

[12] Abou-Zeid, A., et al., Data flow model for communications between project participants in a highway bridge project. Canadian Journal of Civil Engineering, 1995. 22(6): p. 1224-1234.

[13] Lee, E.-B. and D.K. Thomas, State-of-practice technologies on accelerated urban highway rehabilitation: I-15 California experience. Journal of Construction Engineering and Management, 2007. 133(2): p. 105-113.

[14] Liu, B., X.-Y. Huang, and N.-N. Yan, Construction of manufacturing execution system and its application at Shougang. Kang T'ieh/Iron and Steel (Peking), 2006. 41(12): p. 79-82. 
[15] Woo, D.-C., Robotics in highway construction \& maintenance. Public Roads, 1995. 58(3): p. 26-30.

[16] Nichols, M.E. Applications for satellite positioning technology in the construction industry. 1996. Atlanta, GA, USA: IEEE, Piscataway, NJ, USA.
[17] Yang, D.-L., W.-H. Kuo, and M.-S. Chern, Multi-family scheduling in a two-machine reentrant flow shop with setups. European Journal of Operational Research, 2008. 187(3): p. 1160-1170. 